\title{
SHORT CONTRIBUTION
}

\section{On the possibility of barotropic instability over northeast Brazil}

\author{
By VADLAMUDI BRAHMANANDA RAO, VALDO DA SILVA MARQUES' and JOSE PAULO \\ BONATTI, Conselho Nacional de Desenvolvimento Científico e Tecnologico-CNPq. Instituto de \\ Pesquisas Espaciais-INPE, 12.200, Säo José dos Campos, SP, Brazil
}

(Manuscript received September 20, 1982; in final form May 31, 1983)

\begin{abstract}
The easterly zonal wind profile over northeast Brazil during the rainy season of a heavy rainfall year satisfies the necessary condition for the existence of barotropic instability. The wave with a wavelength of $1250 \mathrm{~km}$ has the highest growth rate, $1.6 \times 10^{-6} \mathrm{~s}^{-1}$ (e-folding time of about 6 days). The zonal wind profile is found to be stable during a dry year. This suggests that it is likely that barotropic instability might contribute to the interannual variations of rainfall over northeast Brazil.
\end{abstract}

\section{Introduction}

Northeast (NE) Brazil is characterized by highly variable interannual rainfall. The deficiency of rainfall in this region often leads to severe drought conditions. There are a few studies which describe the general climatology of this region including the rainfall characteristics (Ratisbona, 1976; Hastenrath and Heller, 1977; Kousky and Chu, 1978; Kousky, 1979, 1980). The rainy season over most of NE Brazil is rather short and occurs in March, April and May (Strang, 1972; Moura and Shukla, 1981). This is related to the position of the intertropical convergence zone, ITCZ, which has its southern most position at this time. There are interannual variations in the latitude of the southward penetration of the ITCZ (Hastenrath and Heller, 1977). Further, Marques et al. (1983) noted changes in the structure of the lower tropospheric easterlies during 2 years of contrasting rainfall over NE Brazil. Westward moving disturbances are noted in tropical easterlies and the presence or absence of these disturbances determines in general, the flood or drought (Riehl, 1954). Thus

\footnotetext{
' Also with the Universidade Federal de Rio de Janeiro, Rio de Janeiro, Brazil.
}

during the years of normal or heavy rainfall one could expect atmospheric conditions favorable for the development of disturbances. Nitta and Yanai (1969) suggested that the disturbances observed in the Marshall Islands $\left(9.00^{\circ} \mathrm{N}, 168.00^{\circ} \mathrm{E}\right)$ region are due to barotropic instability of the easterly zonal current found in the vicinity of the ITCZ. The situation over NE Brazil seems to be similar to that found by Nitta and Yanai. The purpose of the present note is to examine the possible role of barotropic instability in the interannual variations of rainfall over NE Brazil.

\section{Barotropic instability problem}

Stability characteristics of barotropic zonal currents in the atmosphere have been studied by several authors; for instance, Kuo (1949), Platzman (1952), Yanai and Nitta (1968), Nitta and Yanai (1969). Haltiner (1963) and Yanai and Nitta (1968) developed a finite difference method for solving the barotropic instability problem. This is done using the linearized barotropic non-divergent vorticity equation. Assuming that the stream function $\psi$ is

$\psi=\phi(y) e^{l m(x-c n)}$ 
where $\phi(y)$ is the amplitude, we will have

$$
(U-c)\left(\frac{d^{2} \phi}{d y^{2}}-\mu^{2} \phi\right)+\left(\beta-\frac{d^{2} U}{d y^{2}}\right) \phi=0
$$

where $\mu$ is the wave number and $c$ is the complex phase speed, $c=c_{r}+i c_{1}$. Eq. (2) can be written in finite difference form

$$
\begin{aligned}
& \left(U_{k}-c\right)\left[\left(\phi_{k-1}+\phi_{k+1}-2 \phi_{k}\right) /(\Delta y)^{2}-\mu^{2} \phi_{k}\right] \\
& \quad+\left[\beta-\left(U_{k-1}+U_{k+1}-2 U_{k}\right) /(\Delta y)^{2}\right] \phi_{k}=0 .
\end{aligned}
$$

where $\Delta y$ is the distance between two grid points $k$ and $k+1$. At the boundaries $y=0$ and $y=2 b$, the amplitude is required to vanish. When applied to all grid points in the interval 0 to $2 b$ eq. (3) gives the matrix relation

$$
(B-C D) \phi=0
$$

where $(B-c D)$ and $\phi$ are the coefficient matrix and a column vector, respectively. If $D$ is nonsingular the condition for a non-zero solution of $\phi$ is

$\operatorname{Det}\left(D^{-1} B-C l\right)=0$

where $D^{-1}$ is the inverse of $D$ and $I$ the unit matrix. Thus the phase velocities $c$ are the eigenvalues of the matrix $D^{-1} B$. The growth rates $(\mu c i)$ can be determined knowing $c$.

Before discussing the characteristics of the zonal currents over NE Brazil, it would be worthwhile to repeat some of the known results as a check. Thus the stability properties of the zonal currents given by Nitta and Yanai (1969), their eqs. (5) and (6) are calculated. The agreement between our calculations and their results (their Figs. 1 and 2) was excellent.

\section{Barotropic instability of the observed easterly zonal current}

We will now examine the possible barotropic instability of the observed easterly zonal current over NE Brazil for two constrating years. In order to select the wet and dry years, 58 raingauge stations which are uniformly distributed in the NE Brazil were examined for the period 1971-78. It was found that 1974 and 1976 were years of excessive and deficient rainfall respectively. Further details of rainfall analyses were given in Marques et al. (1983). Fig. I shows the latitudinal distribution of the average zonal wind (top panel) and the absolute vorticity (bottom panel) for the rainy season, March, April and May 1974 and 1976 at 850, 700 and $500 \mathrm{mb}$ levels. These profiles were obtained using data from 11 rawin and one pilot balloon stations and represent conditions along $41^{\circ} \mathrm{W}$ approximately. During the wet year 1974 , at 850 and $700 \mathrm{mb}$ levels the gradient of absolute vorticity changes its sign and the necessary condition for the barotropic instability is thus satisfied.

The barotropic instability of the $850 \mathrm{mb}$ zonal wind of 1974 was analysed using the finite difference method of Yanai and Nitta (1968). Fig. 2 shows the growth rate $\left(\mu c_{1}\right)$ in units of $10^{-6}$ days. Following Yanai and Nitta (1968) we included more than 20 subdivisions in the interval $2-22^{\circ} \mathrm{S}$. Boundary conditions were imposed at $2^{\circ}$ and $22^{\circ} \mathrm{S}$. It should be remarked that the boundary conditions used are somewhat arbitrary. From Fig. 2 it can be seen that the wave with a wavelength of $1250 \mathrm{~km}$ has the highest growth rate, $1.6 \times 10^{-6}$ $\mathrm{s}^{-1}$ (e-folding time of about 6 days). This wave has an easterly phase speed of $2.7 \mathrm{~m} \mathrm{~s}^{-1}$. If the daily or monthly mean velocity profiles were used the growth rate of the unstable wave could be larger. However, number of missing observations of the stations over NE Brazil are generally large and no attempt is made here to use the profiles for shorter time intervals.

From Fig. 1 it can be seen that during the dry year 1976, the absolute vorticity increases monotonically with decrease of latitude and the necessary condition for occurrence of barotropic instability $\left(\beta-d^{2} u / d y^{2}=0\right)$ is not met. Thus the zonal wind distribution is unfavorable for the growth of the disturbances.

\section{Concluding remarks}

Observed zonal wind profiles over NE Brazil during the rainy season (March, April and May) of heavy rainfall and dry years were examined for barotropic instability. It was found that during the wet year 1974, the easterly zonal wind was unstable. During the dry year 1976, the zonal wind was found to be stable. Thus it can be concluded that barotropic instability seems to play an important role in the interannual variations of rainfall over NE Brazil.

Regarding the other possible mechanisms for the amplification of the disturbances over NE Brazil, 

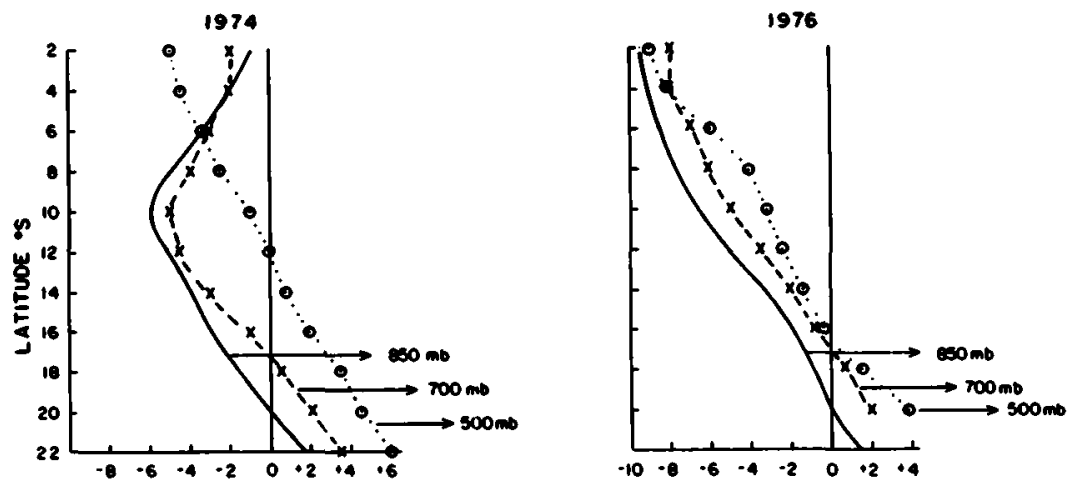

ZONAL WIND $\left(m s^{-1}\right)$
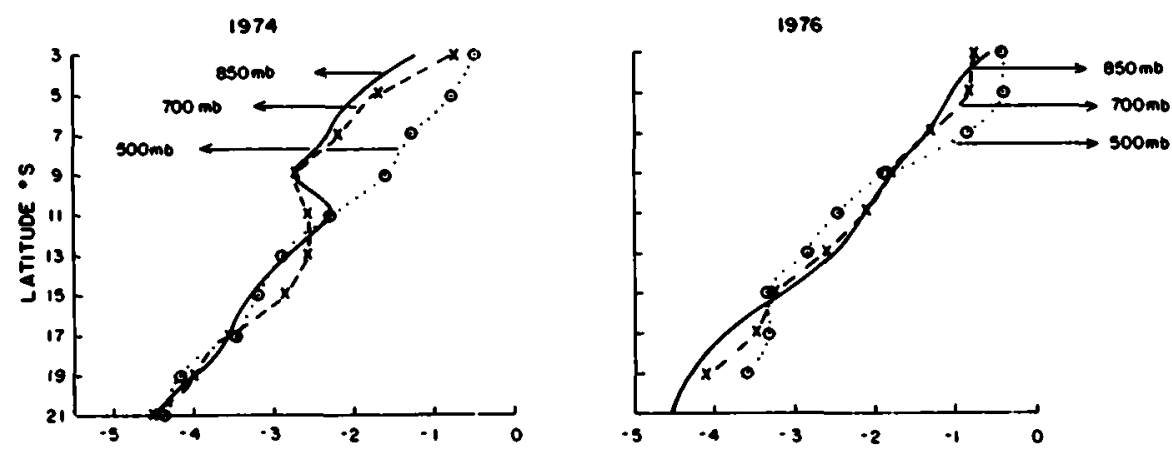

AESOLUTE VORTICITY $\left(10^{-5}:^{-1}\right)$

Fig. 1. The Zonal wind and the corresponding absolute vorticity observed over Northeast Brazil during March, April and May 1974 and 1976.

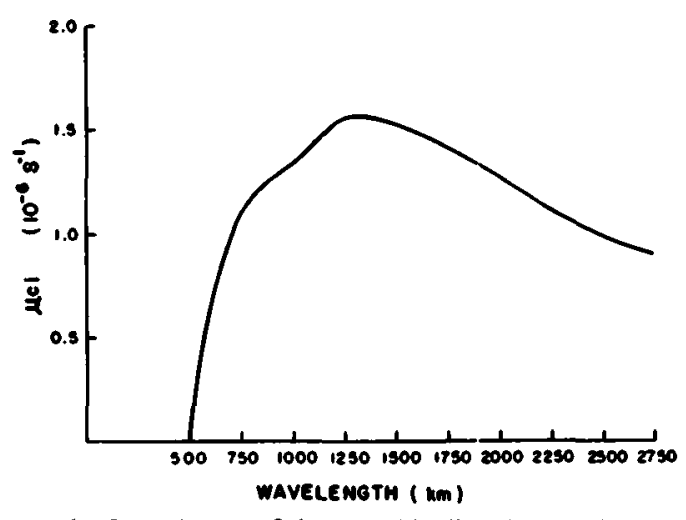

Fig. 2. Growth rate of the unstable disturbances for the $850 \mathrm{mb}$ zonal wind profile of 1974 .

heating by convective clouds may play some role. In an earlier study, it has been found by one of the authors (Marques, 1981) that the thermodynamic structure of the atmosphere over NE Brazil during the rainy season is similar to that found over other tropical regions, where heating by convective clouds is known to play an important role.

\section{Acknowledgements}

Thanks are due to Dr. N. J. Parada for his interest. We are grateful to Dr. A. D., Moura for many useful suggestions. We would like to thank Drs. V. E. Kousky, Pedro L. S. Dias and P. Satyamurty for going through the manuscript. Thanks are also due to editorial reviewers for very helpful comments on early versions of the manuscript. This work is partially supported by Convẽnio No. B/77/81/350/00/00 FINEP/CNPqINPE. 


\section{REFERENCES}

Haltiner, G. J. 1963. Finite difference approximation for the determination of dynamical stability. Tellus 15 , 230-240.

Hastenrath, S. and Heller, L. 1977. Dynamics of climatic hazards in northeast Brazil. Q.J.R. Meteorol. Soc. $103,77-92$.

Kousky, V. E. 1979. Frontal infiuences on northeast Brazil. Mon. Wea. Rev. 107, 1140-1153.

Kousky, V. E. 1980. Diumal rainfall variation in northeast Brazil. Mon. Wea. Rev. 108, 488-498.

Kousky, V. E. and Chu, P. S. 1978. Fluctuations in annual rainfall for northeast Brasil. J. Meteorol. Soc. Japan 57, 457-465.

Kuo, H. L. 1949. Dynamical instability of two-dimensional nondivergent flow in a barotropic atmosphere. J. Meteorol. 6, 105-122.

Marques, V.S. 1981. Estudos da energética e do fluxo de vapor d'água na atmosfera sobre o Nordeste Brasileiro (Studies on the energetics and water vapor flux in the atmosphere over Northeast Brazil). Doctoral thesis, $182 \mathrm{pp}$. (Available from Instituto de Pesquisas Espaciais, INPE, C.P. 515. São José dos Campos, São Pauli, Brazil.)

Marques, V. S., Brahmananda Rao, V. and Molion, L. C. B. 1983. Inter-annual and seasonal variations in the structure and energetics of the atmosphere over northeast Brazil. Tellus 35A, 136-148.

Moura, A. D. and Shukla, J. 1981. On the dynamics of droughts in Northeast Brazil: observations, theory and numerical experiments with a general circulation model. J. Atmos. Sci. 38, 2653-2675.

Nitta, T. and Yanai, M. 1969. A note on the barotropic instability of the tropical easterly current. J. Meteorol. Soc. Japan 47, 127-130.

Platzman, G. W. 1952. The increase of mean flow energy in large-scale horizontal flow in the atmosphere. $J$. Meteorol. 9, 347-358.

Ratisbona, C. R. 1976. The climate of Brazil. In World survey of climatology, Vol. 12 (eds. Schwerdtfeger, W. and Landsberg, H. E.). Amsterdam, Elsevier, 219293.

Riehl, H. 1954. Tropical meteorology. New York: McGraw-Hill.

Strang, D. M. G. 1972. Climatological analysis of rainfall normals in Northeast Brasil. Pap. No. IAE-MO2/72. (Available from Centro Técnico Aerospacial, 12.200, São José dos Campos, S.P., Brazil.)

Yanai, M. and Nitta, T. 1968. Finite difference approximations for the barotropic instability problem. $J$. Meteorol. Soc. Japan 46, 389-403. 